\title{
Pengenalan Keselamatan Dan Kesehatan Kerja Di PT Cita Rasa Palembang
}

\author{
Utami Wahyuningsih ${ }^{1}$; Eko Sulistiyo ${ }^{2}$; Halim Rusjdi ${ }^{3}$; Win Alfalah $^{4}$; \\ Sudirmanto $^{5}$; Eri Prabowo ${ }^{6}$
}

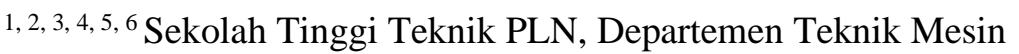

${ }^{1}$ utami@itpln.ac.id

\begin{abstract}
Occupational Safety and Health now occupies an important place in the company, especially in industrial work. A sense of security and comfort at work is a demand for companies to be able to fulfill it in order to provide job security for workers. This study aims to evaluate the implementation of $\mathrm{K} 3$ in the implementation of work in the small industry of Pempek Belida in PT Cita Rasa Palembang based on SMK3. The study used survey questionnaires and direct interviews in the field, followed by identification of industrial locations, visual surveys in the industry and documentation taking in the field. At PT Cita Rasa Palembang, the implementation of Occupational Safety and Health (K3) has been going quite well, because in this Industry the work organizers have provided personal protective equipment (PPE) for workers and the socialization of $K 3$ has also been carried out by the owners and workers quite understand it but there are still impressive workers who do not care about the Occupational Safety and Health, it can be seen from the results of the questionnaire stated, 100\% (Yes) because the work of the food industry has provided personal protective equipment (PPE); 98\% know what is meant by Occupational Safety and Health; and 100\% of workers claim there is a guarantee of Occupational Safety and Health.
\end{abstract}

Keywords: Implementation of Occupational Safety and Health (K3), training, personal protective equipment, industry, workers

\begin{abstract}
ABSTRAK
Keselamatan dan Kesehatan Kerja sekarang ini telah menduduki tempat yang penting dalam perusahaan terutama dalam pekerjaan industri. Rasa aman dan nyaman dalam bekerja merupakan tuntutan bagi perusahaan untuk dapat memenuhinya dalam rangka memberikan jaminan kerja bagi pekerja. Penelitian ini bertujuan untuk mengevaluasi implementasi K3 dalam pelaksanaan pekerjaan pada industri kecil Pempek Belida di PT Cita Rasa Palembang dengan berpatokan pada SMK3. Penelitian menggunakan questioner survei dan wawancara langsung di lapangan, dilanjutkan dengan identifikasi lokasi industri, survei secara visual di industri dan pengambilan dokumentasi dilapangan. Pada PT Cita Rasa Palembang, implementasi Keselamatan dan Kesehatan Kerja (K3) sudah berjalan cukup baik karena di Industri ini penyelenggara pekerjaan telah menyediakan alat pelindung diri (APD) bagi para pekerja dan adanya sosialisasi tentang K3 juga sudah dilakukan oleh pihak pemilik dan para pekerja cukup memahaminya namun masih ada saja pekerja yang berkesan tidak peduli dengan Keselamatan dan Kesehatan kerja tersebut, dapat dilihat dari hasil questioner menyatakan, $100 \%$ (Ya) karena pekerjaan industri makanan telah memberikan alat pelindung diri (APD); 98\% mengetahui apa yang dimaksud dengan Keselamatan dan Kesehatan Kerja; dan 100\% pekerja menyatakan adanya jaminan Keselamatan dan Kesehatan Kerja.
\end{abstract}

Kata kunci: Implementasi Keselamatan dan Kesehatan kerja (K3), pelatihan, alat pelindung diri, pemerintah, industri, pekerja 


\section{PENDAHULUAN}

Dalam sebuah industri juga ada aktivitas pekerjaan yang memiliki risiko kegagalan, salah satunya adalah kecelakaan kerja (work accident), yang berakibat kerugian (loss). Untuk itu perlu Keselamatan dan Kesehatan Kerja (K3) harus terpadu semua orang yang terdapat dalam lingkungan Industri / pekerjaan. Saat ini degradasi keselamatan terjadi akibat transisi dari masyarakat agraris (low risk society) menuju masyarakat industri (high risk society). Pada akhirnya sebuah kecelakaan dapat berdampak pada daya saing tingkat global. Sedangkan masalahnya sebgian masyarakat merasakan tidak memerlukan K3, bahkan dianggap sebagai barang mewah.

Keselamatan dan Kesehatan Kerja adalah semua kondisi dan faktor yang dapat berdampak pada Keselamatan dan kesehatan Kerja bagi tenaga kerja maupun orang lain ditempat kerja, dimana diatur dalan Undang - Undang Republik Indonesia No.1/1970 tentang keselamatan kerja yang mendefinisikan tempat kerja sebagai ruangan atau lapangan, tertutup atau terbuka, bergerak atau tetap dimana tenaga kerja bekerja. Termasuk tempat kerja ialah semua ruangan, lapangan, halaman dan sekelilingnya yang merupakan bagian-bagian atau berhungan dengan tempat kerja tesebut.

Berdasarkan latar belakang di atas rumusan masalah yang dapat ditemukan adalah bagaimana mengenalkan K3 umum untuk pekerja Industri Kecil diwilayah Sumatra Selatan yaitu Palembang.karena itulah kami dari pihak Pengabdian Pada Masyarakat ingin menjembataninya dengan mengadakan pelatihan melalui 'PENGENALAN KESELAMATAN DAN KESEHATAN

\section{KERJA DI PT CITA RASA PALEMBANG'.}

Pada pelaksanaannya K3 memiliki fungsi yang cukup banyak dan bermanfaat baik bagi perusahaan maupun bagi pekerja. Beberapa fungsi K3 secara umum. Sebagai pedoman untuk melakukan identifikasi dan penilaian akan adanya risiko dan bahaya bagi keselamatan dan kesehatan dilingkungan kerja, membantu memberikan saran dalam perencanaan, proses organisir, desain tempat kerja, dan pelaksanaan kerja, sebagai pedoman dalam memantau kesehatan dan keselamatan para pekerja di lingkungan kerja, memberikan saran mengenai informasi, edukasi, dan pelatihan mengenai kesehatan dan keselamatan kerja, sebagai pedoman dalam membuat desain pengendalian bahaya, metode, prosedur dan program, sebagai acuan dalam mengukur keefektifan tindakan pengendalian bahaya dan program pengendalian bahaya. Inti permasalahan yang dihadapi adalah belum mengenal $\mathrm{K} 3$ dan melakukan pelatihan dan pengenalan $\mathrm{K} 3$.

\section{METODE}

Pengenalan K3 untuk pekerja di PT Cita Rasa Palembang dilakukan dalam satu sesi diikuti oleh 20 pekerja. Kegiatan ini dilaksanakan dalam waktu 5 jam. Setiap peserta akan diberikan materi berupa pengetahuan dan ketrampilan. Kedua metode yang digunakan dalam pengabdian kepada masyarakat ini dapat dijabarkan sebagai berikut:

\subsection{PENDIDIKAN MASYARAKAT}

Para peserta diberikan penyuluhan yang bertujuan meningkatkan pemahaman serta kesadaran mereka agar lebih berhati - hati dalam melakukan pekerjaannya masing - masing yang banyak berhubungan dengan peralatan - peralatan logam. Apabila tidak berhati - hati akan membahayakan keselamatan mereka sendiri

\subsection{PELATIHAN}

Peserta pelatihan diberikan teori tentang K3. Setelah mendapatkan teori tentang K3 pekerja diminta untuk mempraktikkan secara langsung K3 di dunia kerja. Setiap pekerja diminta memahami K3 dengan sesi tanya jawab. 
Dengan menempuh 2 metode ini, pengenalan K3 selesai dan para peserta akan mendapatkan sertifikat pelatihan telah mengikuti pengenalan. Setelah pelatihan di atas, tim penyelenggara PkM mendata efektivitas PkM ini. Jenis dan sumber data yang diperlukan dalam penelitian ini terdiri dari data primer. Data primer adalah data yang didapat dari sumber pertama baik dari individu atau perseorangan, seperti dari wawancara atau pengisian kuesioner yang dilakukan oleh peneliti (Umar, 2005:42).

Sumber data adalah peserta yang dimintai tanggapan melalui kuesioner yang diberikan. Metode pengumpulan data yang digunakan adalah angket atau kuesioner. Kuesioner adalah sejumlah pertanyaan secara tertulis yang akan dijawab oleh responden penelitian, agar peneliti memperoleh data lapangan/empiris untuk memecahkan masalah penelitian dan menguji hipotesis yang telah ditetapkan (Supardi, 2005:127).

\section{PEMBAHASAN}

\subsection{PENGERTIAN KESELAMATAN DAN KESEHATAN KERJA}

Pengertian K3 adalah bidang yang berhubungan dengan keselamatan, kesehatan, dan kesejahteraan manusia yang bekerja pada sebuah institusi ataupun lokasi proyek. Arti K3 (Keamanan, Kesehatan, dan Keselamatan Kerja) secara khusus dapat dibagi menjadi dua, yaitu:

1. Pengertian K3 secara keilmuan; K3 merupakan ilmu pengetahuan dan penerapannya dalam upaya mencegah terjadinya kecelakaan dan penyakit akibat kerja.

2. Pengertian K3 secara filosofis; suatu upaya yang dilakukan untuk memastikan keutuhan dan kesempurnaan jasmani dan rohani tenaga kerja pada khususnya, dan masyarakat pada umumnya terhadap hasil karya dan budaya menuju masyarkat adil dan makmur.

Keamanan, Kesehatan, dan Keselamatan Kerja (K3) merupakan salah satu hal penting yang wajib diterapkan oleh semua perusahaan. Hal ini juga tertuang dalam Undang-Undang Ketenagakerjaan No. 13 Tahun 2003 pasal 87.

\subsection{TUJUAN KESELAMATAN DAN KESEHATAN KERJA}

Menurut UU No. 1 Tahun 1970 Tentang Keselamatan Kerja, tujuan dari K3 adalah mencegah terjadinya kecelakaan dan sakit dikarenakan pekerjaan. Selain itu, K3 juga berfungsi untuk melindungi semua sumber produksi agar dapat digunakan secara efektif. Berikut ini adalah fungsi dan tujuan K3 secara umum:

1. Untuk melindungi dan memelihara kesehatan dan keselamatan tenaga kerja sehingga kinerjanya dapat meningkat.

2. Untuk menjaga dan memastikan keselamatan dan kesehatan semua orang yang berada di lingkungan kerja.

3. Untuk memastikan sumber produksi terpelihara dengan baik dan dapat digunakan secara aman dan efisien.

Dalam pelaksaannya banyak ditemui hambatan dalam penerapan K3 dalam dunia pekerja, hal ini terjadi karena beberapa faktor yaitu:

Dari sisi masyarakat pekerja:

1. Tuntutan pekerja masih pada kebutuhan dasar (upah dan tunjangan kesehatan/kesejahtraan).

2. K3 belum menjadi tuntutan pekerja. 
Dari sisi pengusaha:

Pengusaha lebih menekankan penghematan biaya produksi dan meningkatkan efisiensi untuk mendapatkan keuntungan sebesar-besarnya.dan K3 dipandang sebagai beban dalam hal biaya operasional tambahan

Keselamatan dan kesehatan kerja (K3) merupakan instrumen yang memproteksi pekerja, perusahaan, lingkungan hidup, dan masyarakat sekitar dari bahaya akibat kecelakaan kerja. Perlindungan tersebut merupakan hak asasi yang wajib dipenuhi oleh perusahaan. K3 bertujuan mencegah, mengurangi, bahkan menihilkan risiko kecelakaan kerja (zero accident). Penerapan konsep ini tidak boleh dianggap sebagai upaya pencegahan kecelakaan kerja dan penyakit akibat kerja yang menghabiskan banyak biaya (cost) perusahaan, melainkan harus dianggap sebagai bentuk investasi jangka panjang yang memberi keuntungan yang berlimpah pada masa yang akan datang.

Menurut Sumakmur (1988) kesehatan kerja adalah spesialisasi dalam ilmu kesehatan/kedokteran beserta prakteknya yang bertujuan, agar pekerja/masyarpekerja beserta memperoleh derajat kesehatan yang setinggi-tingginya, baik fisik, atau mental, maupun sosial, dengan usaha-usaha preventif dan kuratif, terhadap penyakit-penyakit/gangguan -gangguan kesehatan yang diakibatkan faktor-faktor pekerjaan dan lingkungan kerja, serta terhadap penyakitpenyakit umum.

\subsection{KESELAMATAN KERJA SAMA DENGAN HYGIENE PERUSAHAAN}

Kesehatan kerja memiliki sifat sebagai berikut:

1. Sasarannya adalah manusia

2. Bersifat medis.

Pengertian sehat senantiasa digambarkan sebagai suatu kondisi fisik, mental dan sosial seseorang yang tidak saja bebas dari penyakit atau gangguan kesehatan melainkan juga menunjukan kemampuan untuk berinteraksi dengan lingkungan dan pekerjaannya.Paradigma baru dalam aspek kesehatan mengupayakan agar yang sehat tetap sehat dan bukan sekedar mengobati, merawat atau menyembuhkan gangguan kesehatan atau penyakit.Oleh karenanya, perhatian utama dibidang kesehatan lebih ditujukan ke arah pencegahan terhadap kemungkinan timbulnya penyakit serta pemeliharaan kesehatan seoptimal mungkin.

Status kesehatan seseorang, menurut blum (1981) ditentukan oleh tiga faktor yakni:

1. Lingkungan, berupa lingkungan fisik (alami, buatan) kimia (organik / anorganik, logam berat, debu), biologik (virus, bakteri, microorganisme) dan sosial budaya (ekonomi, pendidikan, pekerjaan).

2. Perilaku yang meliputi sikap, kebiasaan, tingkah laku.

3. pelayanan kesehatan: promotif, perawatan, pengobatan, pencegahan kecacatan, rehabilitasi, dan genetik, yang merupakan faktor bawaan setiap manusia.

Demikian pula status kesehatan pekerja sangat mempengaruhi produktivitas kerjanya.Pekerja yang sehat memungkinkan tercapainya hasil kerja yang lebih baik bila dibandingkan dengan pekerja yang terganggu kesehatannya".Menurut Suma'mur (1976) Kesehatan kerja merupakan spesialisasi ilmu kesehatan/kedokteran beserta prakteknya yang bertujuan agar pekerja/ masyarakat pekerja memperoleh derajat kesehatan setinggi-tingginya baik fisik, mental maupun sosial dengan usaha preventif atau kuratif terhadap penyakit/ gangguan kesehatan yang diakibatkan oleh faktor pekerjaan dan lingkungan kerja serta terhadap penyakit umum.Konsep kesehatan kerja dewasa ini 
semakin banyak berubah, bukan sekedar "kesehatan pada sektor industri" saja melainkan juga mengarah kepada upaya kesehatan untuk semua orang dalam melakukan pekerjaannya.

Keselamatan kerja adalah keselamatan yang bertalian dengan mesin, pesawat, alat kerja, bahan, dan proses pengolahannya, landasan tempat kerja dan lingkungannya serta cara-cara melakukan pekerjaan (Sumakmur, 1993). Keselamatan kerja memiliki sifat sebagai berikut: Sasarannya adalah lingkungan kerja, bersifat teknik.

Pengistilahan Keselamatan dan Kesehatan kerja (atau sebaliknya) bermacam macam; ada yang menyebutnya Higiene Perusahaan dan Kesehatan Kerja (Hyperkes) dan ada yang hanya disingkat K3, dan dalam istilah asing dikenal Occupational Safety and Health. Keselamatan kerja atau Occupational Safety, dalam istilah sehari hari sering disebut dengan safety saja, secara filosofi diartikan sebagai suatu pemikiran dan upaya untuk menjamin keutuhan dan kesempurnaan baik jasmaniah maupun rohaniah tenaga kerja pada khususnya dan manusia pada umumnya serta hasil budaya dan karyanya. Dari segi keilmuan diartikan sebagai suatu pengetahuan dan penerapannya dalam usaha mencegah kemungkinan terjadinya kecelakaan dan penyakit akibat kerja.

Pengertian Kecelakaan Kerja (accident) adalah suatu kejadian atau peristiwa yang tidak diinginkan yang merugikan terhadap manusia, merusak harta benda atau kerugian terhadap proses.Dewasa ini pembangunan nasional tergantung banyak kepada kualitas, kompetensi dan profesionalisme sumber daya manusia termasuk praktisi keselamatan dan kesehatan kerja (K3).Dari segi dunia usaha diperlukan produktivitas dan daya saing yang baik agar dapat berkiprah dalam bisnis internasional maupun domestik.Salah satu faktor yang harus dibina sebaik-baiknya adalah implementasi K3 dalam berbagai aktivitas masyarakat khususnya dalam dunia kerja. Pengertian Hampir Celaka, yang dalam istilah safety disebut dengan insiden (incident), ada juga yang menyebutkan dengan istilah "near-miss" atau "near-accident", adalah suatu kejadian atau peristiwa yang tidak diinginkan dimana dengan keadaan yang sedikit berbeda akan mengakibatkan bahaya terhadap manusia, merusak harta benda atau kerugian terhadap proses kerja.

Ada tiga aspek utama hukum K3 yaitu norma keselamatan, kesehatan kerja, dan kerja nyata. Norma keselamatan kerja merupakan sarana atau alat untuk mencegah terjadinya kecelakaan kerja yang tidak diduga yang disebabkan oleh kelalaian kerja serta lingkungan kerja yang tidak kondusif.

Konsep ini diharapkan mampu menihilkan kecelakaan kerja sehingga mencegah terjadinya cacat atau kematian terhadap pekerja, kemudian mencegah terjadinya kerusakan tempat dan peralatan kerja. Konsep ini juga mencegah pencemaran lingkungan hidup dan masyarakat sekitar tempat kerja. Norma kesehatan kerja diharapkan menjadi instrumen yang mampu menciptakan dan memelihara derajat kesehatan kerja setinggi-tingginya.

\subsection{GAMBARAN UMUM LOKASI PENELITIAN}

PT Cita Rasa Palembang yang memproduksi pempek Belida berada di lorong Mawar, Suka Maju, Kec.Sako, Kota Palembang, Sumatera Selatan 30961, dimana kami melakukan pengenalan K3 untuk pekerja di PT Cita Rasa Palembang. 
Berikut foto-foto sosialisasi pengenalan K3:

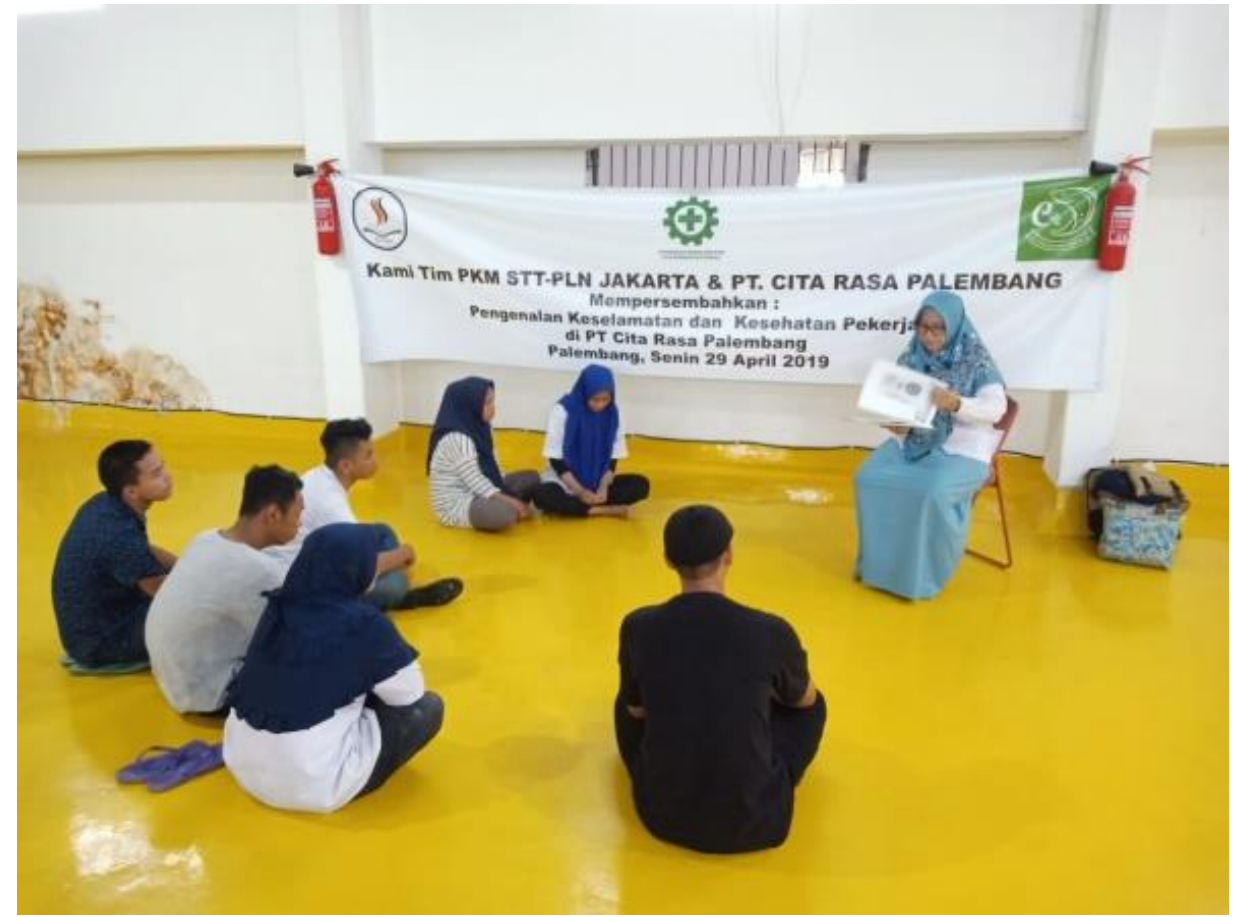

Gambar 1. Pemberian pengetahuan dasar K3

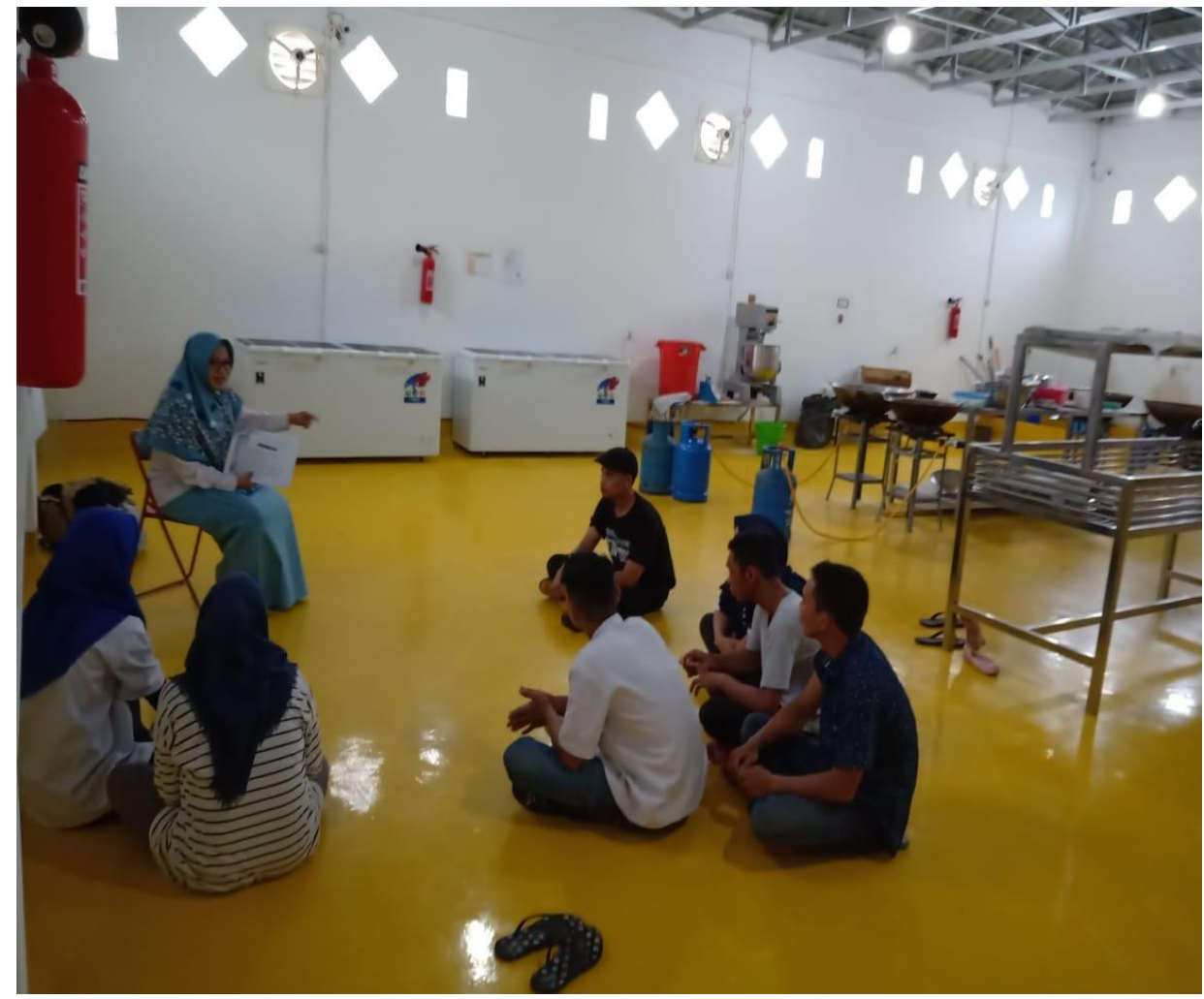

Gambar 2. Pemberian penjelasan tentang pentingnya APD dan K3

\subsection{ALAT PELINDUNG DIRI PADA INDUSTRI PEMBUATAN PEMPEK}

Terdapat beberapa dapur besar dan penuh alat-alat yang rumit dan beresiko apabila tidak digunakan dengan baik dan benar. Karenanya diperlukan alat keselamatan supaya mereka yang 
bekerja didapur tidak di alami kemungkinan kecelakaan berat atau bahkan juga kematian. Umpamanya saja dapur pada perusahaan catering, dapur restoran, dapur hotel, dapur tempat tinggal makan atau warung, dan yang lainnya.

Berikut adalah cara melindungi keselamatan di dapur:

1. Untuk menghindar terbakar, maka upayakan tak menggunakan baju atau pakaian lengan panjang saat memasak. Api dapat dengan gampang menyambar pakaian lengan panjang jika lengah, hingga baiknya gulung sampai ke siku jika menggunakan lengan panjang.

2. Jauhi menempatkan buku resep, kain lap yang gampang terbakar, atau bungkus makanan dari kertas di dekat kompor. Jauhkan juga korek api, terlebih korek api gas dari kompor, ini menghindarkan terjadinya kebakaran.

3. Sepatu safety dan celemek. Ini yaitu perengkapan yang harus dipakai oleh beberapa koki yang bekerja di dapur. Sepatu akan melindungi kaki dari luka akibat zat kimia atau dari jatuhnya pisau. Tengah celemek akan melindungi badan dari cipratan minyak atau air panas.

4. Hati-hati dengan tabung gas untuk kompor. Pakai regulator yang baik, supaya saat kompor dinyalakan gas tak bocor. Selekasnya ubah regulator apabila longgar atau periode waktu penggunaannya telah habis.

5. Untuk dapur besar, senantiasa siapkan alat pemadam kebakaran portable, ini akan begitu bermanfaat jika berlangsung kebakaran. Apabila didapur tempat tinggal, dapat pakai handuk basah untuk memadamkan api, atau ambillah garam dan siramkan di api.

Kunci dari keselamatan di dapur yaitu diri sendiri, tidak boleh lengah, lupa meninggalkan kompor dalam kondisi menyala, atau sangat tergesa-gesa dan kehilangan sikap tenang. Alat-alat keselamatan kerja dan manfaatnya di dapur itu akan optimal apabila tetap tenang dan dapat menguasai emosi supaya tidak cemas.

Secara umum penelitian ini menunjukkan hasil yang cukup memuaskan. Hasil analisis deskriptif menunjukkan bahwa kualitas pelayanan yang diberikan oleh STT PLN secara umum sudah baik. Hal ini dapat ditunjukkan dari banyaknya tanggapan kepuasan yang tinggi dari responden terhadap kondisi dari masing-masing variabel penelitian. Dari hasil tersebut selanjutnya diperoleh bahwa variabel kualitas pelayanan dalam kelima dimensinya memiliki pengaruh yang positif dan signifikan terhadap kepuasan konsumen. Hal ini dikarenakan bahwa dengan pemberian pelayanan yang berkualitas, maka hal tersebut akan menciptakan kepuasan dalam diri peserta pelatihan.

\section{KESIMPULAN}

Kurang menyadari dan kurang memahami akan Keselamatan dan Kesehatan Kerja (K3) untuk pekerja PT Cita Rasa Palembang terpenuhi sudah karena dengan dilakukan pengenalan K3 ini pekerja bertambah pengetahuannya sehingga kelak menjadi bekal keahlian dalam menyadari pentingnya melindungi diri untuk Keselamatan dan Kesehatan Kerja dalam lingkungan kerja.

\section{SARAN}

Sebaiknya ditingkatkan terus yang menjadi kepuasan peserta sebagai tolak ukur di kemudian hari jika ingin mengadakan pelatihan lagi, peserta juga ditambah dari seluruh industri kecil di Indonesia. 


\section{UCAPAN TERIMA KASIH}

Dengan terlaksananya kegiatan ini Tim P2M Jurusan Teknik Mesin STT-PLN mengucapkan terima kasih kepada KLPPM STT PLN dan Himpunan Mahasiswa Teknik Mesin atas bantuannya yang tidak ternilai sehingga semua rencana kegiatan P2M pada semester Ganjil tahun akademik 2017/2018 ini terlaksana dengan baik.

\section{DAFTAR PUSTAKA}

[1] Sugiyono, "Keselamatan dan Kesehatan Kerja “, materi K3 Bagian 1.

[2] Mg Catur Yuantari, "Dasar K3", materi K3.

[3] Sihombing D. R. O. Walangitan, A. K. Pingkan "IMPLEMENTASI KESELAMATAN DAN KESEHATAN KERJA (K3) PADA PROYEK DI KOTA BITUNG (STUDI KASUS PROYEK PEMBANGUNAN PABRIK MINYAK PT. MNS)". Jurnal Sipil Statik Vol. 2 No.3, Maret 2014 (124-130). ISSN: 2337-6732

[4] Tarwaka, "Keselamatan dan Kesehatan Kerja Manajemen Implementasi di Tempat kerja", edisi II cetakan 1, Harapan Press, 2014

[5] Aeni Heni Fa'riatul, Sriagustni Isyeu, "Keselamatan dan Kesehatan Kerja", Yogjakarta, 2018

[6] Ramli Soehatman, "Sistem Manajemen Keselamatan dan Kesehatan Kerja OHSAS 18001, Dian Rakyat,2018 